\title{
Aureliella helgolandensis gen. nov., sp. nov., a novel Planctomycete isolated from a jellyfish at the shore of the island Helgoland
}

\author{
Nicolai Kallscheuer • Sandra Wiegand $\cdot$ Christian Boedeker $\cdot$ Stijn H. Peeters • \\ Mareike Jogler - Patrick Rast - Anja Heuer - Mike S. M. Jetten • \\ Manfred Rohde $\cdot$ Christian Jogler
}

Received: 20 January 2020/Accepted: 6 March 2020/Published online: 27 March 2020

(C) The Author(s) 2020

\begin{abstract}
A novel planctomycetal strain, designated Q31 $\mathrm{a}^{\mathrm{T}}$, was isolated from a jellyfish at the shore of the island Helgoland in the North Sea. The strain forms lucid white colonies on solid medium and displays typical characteristics of planctomycetal strains, such as division by budding, formation of rosettes, presence of crateriform structures, extracellular matrix or fibre and a holdfast structure. Q31 ${ }^{\mathrm{T}}$ is mesophilic (temperature optimum $27^{\circ} \mathrm{C}$ ), neutrophilic ( $\mathrm{pH}$ optimum 7.5), aerobic and heterotrophic. A maximal growth rate of $0.017 \mathrm{~h}^{-1}$ (generation time of $41 \mathrm{~h}$ ) was observed. Q31 ${ }^{\mathrm{T}}$ has a genome size of $8.44 \mathrm{Mb}$ and a
\end{abstract}

N. Kallscheuer · S. H. Peeters · M. Jogler .

M. S. M. Jetten · C. Jogler $(\square)$

Department of Microbiology, Radboud University,

Nijmegen, The Netherlands

e-mail: christian@jogler.de

S. Wiegand

Institute for Biological Interfaces 5, Karlsruhe Institute of

Technology, Eggenstein-Leopoldshafen, Germany

C. Boedeker · P. Rast · A. Heuer

Leibniz Institute DSMZ, Brunswick, Germany

M. Jogler · C. Jogler

Department of Microbial Interactions, Institute of Microbiology, Friedrich Schiller University, Jena,

Germany

M. Rohde

Central Facility for Microscopy, Helmholtz Centre for Infection Research, Brunswick, Germany
$\mathrm{G}+\mathrm{C}$ content of $55.3 \%$. Phylogenetically, the strain represents a novel genus and species in the recently introduced family Pirellulaceae, order Pirellulales, class Planctomycetia. We propose the name Aureliella helgolandensis gen. nov., sp. nov. for the novel species, represented by $\mathrm{Q} 31 \mathrm{a}^{\mathrm{T}}\left(=\mathrm{DSM} 103537^{\mathrm{T}}\right.$ $=$ LMG $29700^{\mathrm{T}}$ ) as the type strain.

Keywords Marine bacteria $\cdot$ North Sea $\cdot$ Biotic surfaces · Pirellulaceae

\section{Introduction}

Planctomycetes is a bacterial phylum displaying exceptional physiological and morphological features (Fuerst 1995; Lage et al. 2019; Staley et al. 1992; Ward 2010; Wiegand et al. 2020). Members of this phylum can be found in a variety of different habitats on earth, while the majority of species characterised so far have been isolated from aquatic environments (Wiegand et al. 2018). Phylogenetically, the phylum Planctomycetes, along with Chlamydiae, Verrucomicrobia and others, forms the PVC superphylum, which is of medical and biotechnological relevance (Calisto et al. 2019; Wagner and Horn 2006). Planctomycetes have large genomes of up to $12.4 \mathrm{Mb}$ and usually $40-50 \%$ of the annotated genes are of unknown function (Jogler et al. 2012; Ravin et al. 2018; Wiegand et al. 2020). The taxonomy of the phylum 
Planctomycetes was recently revised (Dedysh et al. 2019). No changes were made to the original division of the phylum into the classes Candidatus Brocadiae, Phycisphaerae and Planctomycetia, while the latter is now further subdivided into the orders Gemmatales, Isosphaerales, Pirellulales and Planctomycetales.

Species belonging to the class Planctomycetia have been isolated from various marine biotic and abiotic surfaces (Boersma et al. 2019; Bondoso et al. 2014, 2017; Kallscheuer et al. 2020; Peeters et al. 2020; Vollmers et al. 2017), on which they can be highly abundant (Bengtsson and Øvreås 2010). Due to the oligotrophic nature of marine environments, such species are suggested to digest complex carbon substrates, e.g. from biotic surfaces to which they frequently attach (Jeske et al. 2013; Lachnit et al. 2013). The observed dominance of planctomycetal species e.g. on algal surfaces is astonishing given their slow growth compared to other natural competitors in this ecological niche, e.g. members of the 'Roseobacter group' (Frank et al. 2014; Wiegand et al. 2018). The underlying mechanisms allowing species of the class Planctomycetia to compensate for slower growth are not understood, but might include the capability to produce bioactive small molecules (Graca et al. 2016; Jeske et al. 2016; Kallscheuer et al. 2019c), their resistance against several antibiotics (Cayrou et al. 2010; Godinho et al. 2019) and a specialised machinery for the uptake and intracellular digestion of complex polysaccharides. The latter is suspected to be facilitated by unique pili-forming crateriform structures and an extremely enlarged periplasmic space (Boedeker et al. 2017).

In the last decade, novel microscopic techniques and genetic tools for Planctomycetes (Jogler et al. 2011; Jogler and Jogler 2013; Rivas-Marin et al. 2016) allowed for a more detailed analysis of the cell envelope architecture of these bacteria. Planctomycetes were shown to possess peptidoglycan (Jeske et al. 2015; van Teeseling et al. 2015), supporting the assumption that all free-living bacteria have a peptidoglycan cell wall. The cell envelope architecture of Planctomycetes is therefore similar to that of Gramnegative bacteria (Boedeker et al. 2017; Devos 2014). However, the phylum Planctomycetes is still exceptional. Characterised members were found to lack canonical divisome proteins including the otherwise universal FtsZ (Jogler et al. 2012; Pilhofer et al. 2008). Members of the class Phycisphaerae divide by binary fission, while budding is performed by species in the class Planctomycetia (Wiegand et al. 2020).

To extend the current collection of axenic cultures and as a basis to further study the interesting cell biology and metabolism of Planctomycetes here we describe strain Q $31 \mathrm{a}^{\mathrm{T}}$ isolated from a jellyfish close to the island Helgoland in the North Sea. According to the results of our analyses, the strain represents a novel species and genus in the recently proposed family Pirellulaceae, order Pirellulales in the class Planctomycetia (Dedysh et al. 2019).

\section{Materials and methods}

\section{Isolation of the novel strain and cultivation}

For the isolation and cultivation of strain $\mathrm{Q} 31 \mathrm{a}^{\mathrm{T}}, \mathrm{M} 1 \mathrm{H}$ NAG ASW medium was used (Kallscheuer et al. 2019a). Strain Q31a ${ }^{T}$ was isolated from a dead common jellyfish (Aurelia aurita) found at the shore of Helgoland Island (exact location 54.188 N 7.875 E) on the 5th of June 2013. A piece of the tentacles was cut off and then swabbed over a M1H NAG ASW plate containing $8 \mathrm{~g} / \mathrm{L}$ gellan gum, $1000 \mathrm{mg} / \mathrm{L}$ streptomycin, $200 \mathrm{mg} / \mathrm{L}$ ampicillin and $20 \mathrm{mg} / \mathrm{L}$ cycloheximide, which was subsequently incubated at $20{ }^{\circ} \mathrm{C}$ for three weeks. The 16S rRNA gene of obtained colonies was amplified by PCR and sequenced following an established protocol (Rast et al. 2017). This step was performed in order to check whether isolated strains represent members of the phylum Planctomycetes. DNA extraction and genome sequencing are described in a previously published study (Wiegand et al. 2020).

\section{Determination of $\mathrm{pH}$ and temperature optimum}

Cultivation for determination of the $\mathrm{pH}$ optimum was performed in M1H NAG ASW medium and for ensuring a stable pH $100 \mathrm{mM}$ HEPES was used for

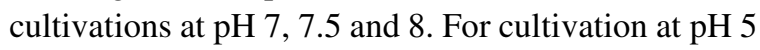
and 6 HEPES was replaced by $100 \mathrm{mM} 2-(N-$ morpholino)ethanesulfonic acid (MES), whereas 100 mM N-cyclohexyl-2-aminoethanesulfonic acid (CHES) served as a buffering agent at $\mathrm{pH} 9$ and 10. Cultivations for determination of the $\mathrm{pH}$ optimum were performed at $28{ }^{\circ} \mathrm{C}$. Cultivations for determination of the temperature optimum were performed in standard M1H NAG ASW medium at $\mathrm{pH}$ 7.5. 
Microscopy protocols

Phase contrast and field emission scanning electron microscopy were performed as previously described (Boersma et al. 2019).

Genome information

Genome and 16S rRNA gene sequence of strain Q31 $\mathrm{a}^{\mathrm{T}}$ are available from GenBank under accession numbers CP036298 and MK559992, respectively. Numbers of carbohydrate-active enzymes were obtained from the CAZY database (Lombard et al. 2014). Gene clusters potentially involved in the production of secondary metabolites were determined using antiSMASH 4.0 (Blin et al. 2017).

\section{Phylogenetic analysis}

16S rRNA gene-based phylogeny was computed for Q31 $\mathrm{a}^{\mathrm{T}}$, the type strains of all described planctomycetal species (assessed in January 2020) and all isolates recently described (Boersma et al. 2019; Kallscheuer et al. 2019a, b, d, 2020; Kohn et al. 2019; Peeters et al. 2020; Rensink et al. 2020). The 16 S rRNA gene sequences were aligned with SINA (Pruesse et al. 2012) and the phylogenetic inference was calculated with RAxML (Stamatakis 2014) with a maximum likelihood approach with 1000 bootstraps, nucleotide substitution model GTR, gamma distributed rate variation and estimation of proportion of invariable sites (GTRGAMMAI option). Three 16S rRNA genes of bacterial strains from the PVC superphylum but outside of the phylum Planctomycetes (GenBank accession numbers AJ229235, KC665948 and NR_027571) were used as outgroup. For the multilocus sequence analysis (MLSA) the unique singlecopy core genome of the analysed genomes (GenBank acc. no. CP036298) was determined with proteinortho5 (Lechner et al. 2011) with the 'selfblast' option enabled. The protein sequences of the resulting orthologous groups were aligned using MUSCLE v.3.8.31 (Edgar 2004). After clipping, partially aligned $C$ - and $N$-terminal regions and poorly aligned internal regions were filtered using Gblocks (Castresana 2000). The final alignment was concatenated and clustered using the maximum likelihood method implemented by RaxML (Stamatakis 2014) with the 'rapid bootstrap' method and 500 bootstrap replicates.
Four planctomycetal genomes from different families were used as outgroup. The average nucleotide identity (ANI) was calculated using OrthoANI (Lee et al. 2016). The average amino acid identity (AAI) was calculated using the aai.rb script of the enveomics collection (Rodriguez-R and Konstantinidis 2016) and the percentage of conserved proteins (POCP) was calculated as described (Qin et al. 2014). The rpoB nucleotide sequences were taken from publicly available planctomycetal genome annotations and the sequence identities were determined as described (Bondoso et al. 2013). Upon extracting only those parts of the sequence that would have been sequenced with the described primer set, the alignment and matrix calculation was performed with Clustal Omega (Sievers et al. 2011).

\section{Results and discussion}

Phylogenetic analysis

Based on 16S rRNA gene phylogeny and whole genome-based MLSA, strain Q31a ${ }^{\mathrm{T}}$ groups within the planctomycetal family Pirellulaceae (Fig. 1). Within this family, its current closest neighbours on $16 \mathrm{~S}$ rRNA gene level are Mariniblastus fucicola and Pirellula staleyi, further close neighbours are Blastopirellula sp. and Bremerella sp. However, supporting bootstrap values in this clade are sometimes rather low and no definitive closest neighbourhood could be determined by MLSA analysis. Therefore, strain Q31a ${ }^{\mathrm{T}}$ was compared to all described genera within the family Pirellulaceae (Fig. 2).

16S rRNA gene sequence identity analysis (Fig. 2) shows that all minimal identities between the novel strain $\mathrm{Q} 31 \mathrm{a}^{\mathrm{T}}$ and the nine most related genera are notably below the genus threshold of $94.5 \%$ that might place Q31a ${ }^{\mathrm{T}}$ in any of these taxa (Yarza et al. 2014). The similarity values for strain $\mathrm{Q} 31 \mathrm{a}^{\mathrm{T}}$ and its relatives are also below the genus threshold values used with rроB nucleotide sequences identities (75.5-78.0\%) (Kallscheuer et al. 2019d), AAI (60-80\%) (Konstantinidis and Tiedje 2005) and POCP (50\%) (Qin et al. 2014) (Fig. 2). With all used methods suggesting the placement of strain $\mathrm{Q} 31 \mathrm{a}^{\mathrm{T}}$ in a novel genus, we conclude the strain represents a novel genus and species within the family Pirellulaceae, for which we 
propose the name Aureliella helgolandensis gen. nov., sp. nov.

Morphological and physiological analyses

Basic features of strain $\mathrm{Q} 31 \mathrm{a}^{\mathrm{T}}$ regarding cell morphology and mechanism of cell division are summarised in Table 1. As we could not identify a current closest relative of $\mathrm{Q} 31 \mathrm{a}^{\mathrm{T}}$, the morphological and genomic features were compared to all strains identified as potential candidates during the phylogenetic analysis. Morphological features of $\mathrm{Q} 31 \mathrm{a}^{\mathrm{T}}$ cells harvested during the exponential growth phase were analysed using phase contrast and scanning electron microscopy (Fig. 3). Cells of strain $\mathrm{Q}_{11}{ }^{\mathrm{T}}$ are $1.9 \pm 0.2 \times 1.0 \pm 0.2 \mu \mathrm{m}$ in size and acorn-shaped (Fig. 3a-c). Cells form aggregates of typically $8-25$ cells, which in turn are often loosely connected to each other (Fig. 3d). Cells divide by polar budding (Fig. 3a). Extracellular matrix or fibre originates from one pole. At this pole crateriform structures can also be observed, which cover around 10-20\% of the cell surface. Daughter cells of Q31a ${ }^{\mathrm{T}}$ have the same shape as the mother cell. The strain follows a dimorphic lifecycle involving sessile mother cells and flagellated daughter cells. Colonies of strain Q31a ${ }^{\mathrm{T}}$ lack pigmentation and have a lucid white colour.

Despite aggregate formation, measurement of optical densities $\left(\mathrm{OD}_{600}\right)$ in liquid cultures was

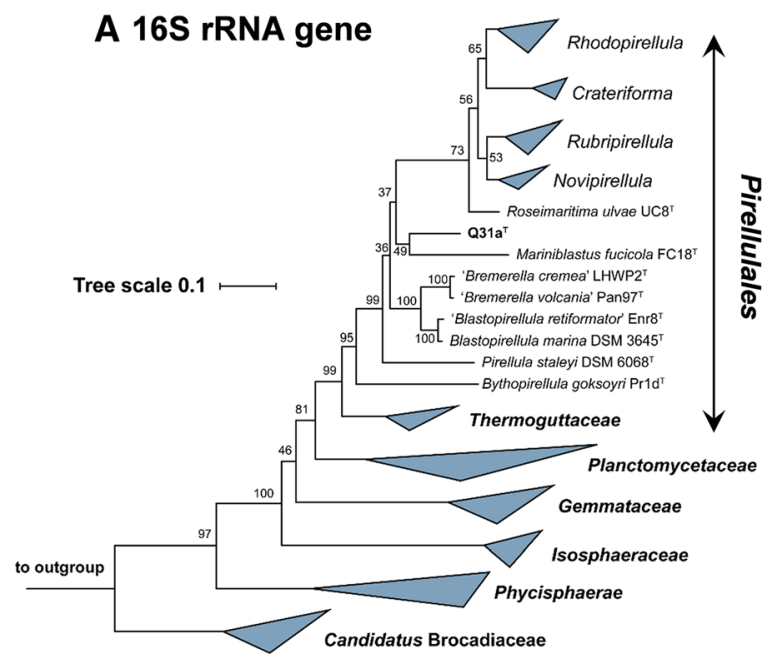

Fig. 1 Maximum likelihood phylogenetic analysis. Phylogenetic trees showing the position of strain $\mathrm{Q} 31 \mathrm{a}^{\mathrm{T}}$. 16S rRNA gene (a) and MLSA-based phylogeny (b) was computed as described possible. In M1H NAG ASW medium, Q31a ${ }^{\mathrm{T}}$ was found to be able to grow in a temperature range of $10-33{ }^{\circ} \mathrm{C}$ and in a $\mathrm{pH}$ range of $6.0-8.0$ (Fig. 4). Optimal growth was observed at $27{ }^{\circ} \mathrm{C}$ and $\mathrm{pH}$ 7.5. The maximal growth rate observed in M1H NAG ASW medium was $0.017 \mathrm{~h}^{-1}$ (Fig. 4), corresponding to a generation time of $41 \mathrm{~h} . \mathrm{Q} 31 \mathrm{a}^{\mathrm{T}}$ is an aerobic heterotroph. During comparison of preferred temperature and $\mathrm{pH}$ of $\mathrm{Q} 31 \mathrm{a}^{\mathrm{T}}$ with the close relatives $M$. fucicola $\mathrm{FC} 18^{\mathrm{T}}$, Blastopirellula marina DSM $3645^{\mathrm{T}}$, Roseimaritima ulvae $\mathrm{UC}^{\mathrm{T}}$, P. staleyi DSM $6068^{\mathrm{T}}$ and Crateriforma conspicua Mal65 ${ }^{\mathrm{T}}$ considerable differences were observed. The temperature optimum of $\mathrm{Q} 31 \mathrm{a}^{\mathrm{T}}$ is between the optima of $P$. staleyi $\left(24^{\circ} \mathrm{C}\right) / \mathrm{M}$. fucicola $\left(25^{\circ} \mathrm{C}\right)$ and the other three strains $\left(30-36^{\circ} \mathrm{C}\right)$ (Table 1). The $\mathrm{pH}$ range for growth of $\mathrm{Q} 31 \mathrm{a}^{\mathrm{T}}$ is narrow compared to ranges of 6.0-10.0 observed for $R$. ulvae and $C$. conspicua, but comparable to $M$. fucicola (for the other two strains no data was available). The lucid white colony colour of $\mathrm{Q} 31 \mathrm{a}^{\mathrm{T}}$ indicates the lack of carotenoid formation of the strain, which is a common feature of $B$. marina and $P$. staleyi, but separates $\mathrm{Q} 31 \mathrm{a}^{\mathrm{T}}$ from the pink-pigmented $R$. ulvae and $C$. conspicua (Table 1).

\section{Genomic characteristics}

The genome of $\mathrm{Q} 31 \mathrm{a}^{\mathrm{T}}$ has a size of $8.44 \mathrm{Mb}$ and $\mathrm{a}$ $\mathrm{G}+\mathrm{C}$ content of $55.3 \%$. The strain lacks plasmids.

\section{B MLSA}

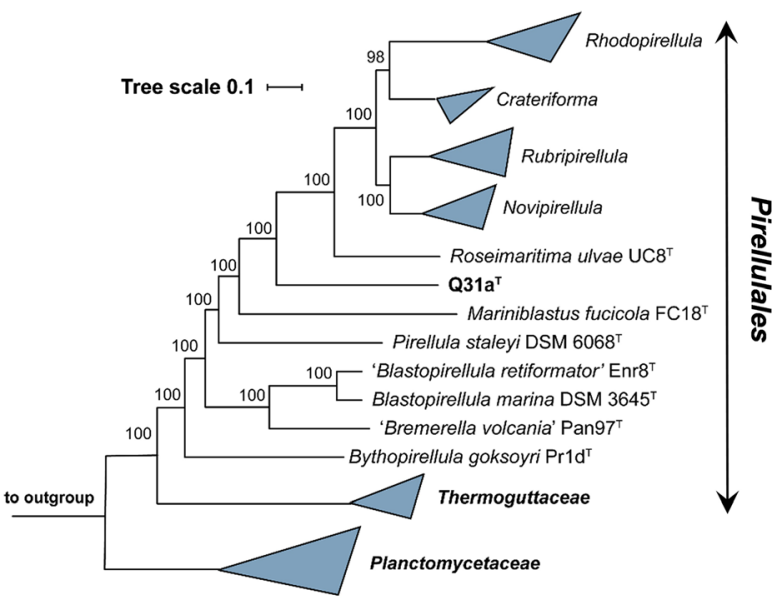

in the "Material and methods" section. Bootstrap values after 1000 re-samplings (16S rRNA gene) or 500 re-samplings (MLSA) are given at the nodes 

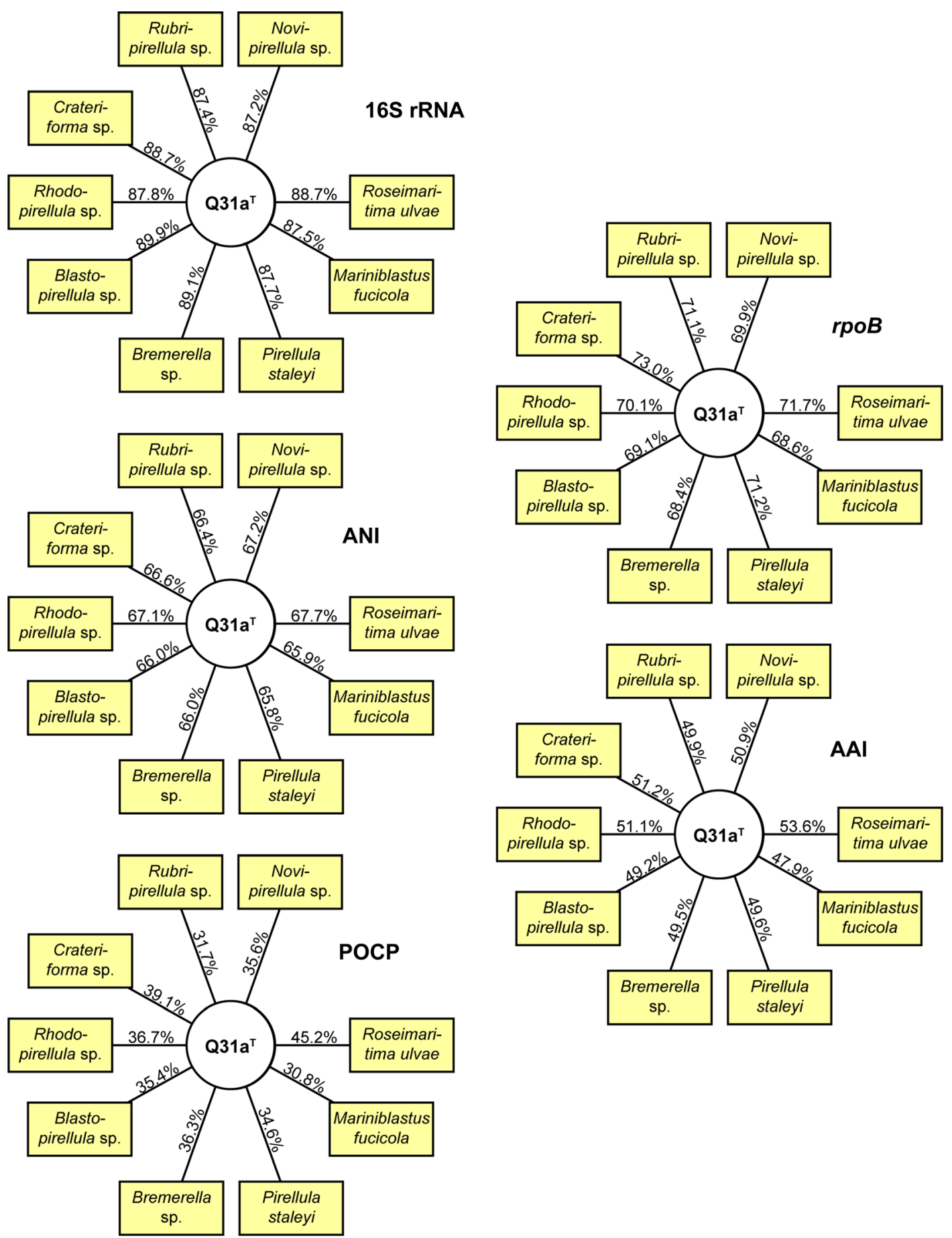

Fig. 2 Phylogenetic marker values of $\mathrm{Q} 31 \mathrm{a}^{\mathrm{T}}$ and its current close neighbours. The numbers give the minimal similarity values shared between Q31 $\mathrm{a}^{\mathrm{T}}$ and any described member of the gene identity, (rpoB) rpoB nucleotide sequences identity, (ANI) average nucleotide identity, (AAI) average amino acid identity and $(\mathrm{POCP})$ percentage of conserved proteins 
Table 1 Phenotypic and genotypic features of strain $\mathrm{Q} 1 \mathrm{a}^{\mathrm{T}}$ compared to closely related strains

\begin{tabular}{|c|c|c|c|c|c|c|}
\hline & $\mathrm{Q}^{31 \mathrm{a}^{\mathrm{T}}}$ & $\begin{array}{l}\text { M. fucicola } \\
\text { FC } 18^{\mathrm{T}}\end{array}$ & $\begin{array}{l}\text { B. marina } \\
\text { DSM } 3645^{\mathrm{T}}\end{array}$ & $\begin{array}{l}\text { R. ulvae } \\
\mathrm{UC8}^{\mathrm{T}}\end{array}$ & $\begin{array}{l}\text { P. staleyi } \\
\text { DSM } 6068^{\mathrm{T}}\end{array}$ & $\begin{array}{l}\text { C. conspicua } \\
\text { Mal65 }^{\mathrm{T}}\end{array}$ \\
\hline \multicolumn{7}{|l|}{ Phenotypic characteristics } \\
\hline Shape & $\begin{array}{l}\text { Acorn- } \\
\text { shaped }\end{array}$ & $\begin{array}{l}\text { Spherical to } \\
\text { ovoid }\end{array}$ & $\begin{array}{l}\text { Ovoid, pear- } \\
\text { shaped }\end{array}$ & $\begin{array}{l}\text { Spherical to } \\
\text { ovoid }\end{array}$ & $\begin{array}{l}\text { Ovoid to } \\
\text { spherical }\end{array}$ & Pear-shaped \\
\hline Size length $(\mu \mathrm{m})$ & $1.9 \pm 0.2$ & $\begin{array}{l}\text { 1.0-2.0 } \\
\text { (diameter) }\end{array}$ & $1.0-2.0$ & $1.1-1.8$ & $1.0-1.5$ & $1.8 \pm 0.3$ \\
\hline Size width $(\mu \mathrm{m})$ & $1.0 \pm 0.2$ & $\begin{array}{l}\text { 1.0-2.0 } \\
\text { (diameter) }\end{array}$ & $0.7-1.5$ & $0.9-1.5$ & $0.9-1.0$ & $1.0 \pm 0.2$ \\
\hline Colony colour & Lucid white & $\begin{array}{l}\text { White to light } \\
\text { pink }\end{array}$ & $\begin{array}{l}\text { Off-white to light } \\
\text { brown }\end{array}$ & Light pink & $\begin{array}{l}\text { Yellowish- } \\
\text { white }\end{array}$ & Pink \\
\hline $\begin{array}{l}\text { Temperature range } \\
\text { (optimum) }\left({ }^{\circ} \mathrm{C}\right)\end{array}$ & $10-33(27)$ & $10-30(25)$ & Up to $35(27-33)$ & $15-35(30)$ & $18-30(24)$ & $10-36(32)$ \\
\hline pH range (optimum) & $6.0-8.0(7.5)$ & $6.5-8.5(7.5)$ & $5.5-8.5(6.5-7.5)$ & $6.5-10.0(7.5)$ & n.d. & $\begin{array}{l}5.0-10.0 \\
(7.5)\end{array}$ \\
\hline Aggregates & Yes & Yes & Yes & Yes, rosettes & Yes, rosettes & Yes, rosettes \\
\hline Division & Budding & Budding & Budding & Budding & Budding & Budding \\
\hline Dimorphic life cycle & Yes & No & Yes & Yes & Yes & Yes \\
\hline Flagella & Yes & No & Yes & Yes & Yes & Yes \\
\hline Crateriform structures & $\begin{array}{l}\text { Yes, at fibre } \\
\text { pole }\end{array}$ & $\begin{array}{l}\text { Yes, at } \\
\text { reproductive } \\
\text { pole }\end{array}$ & $\begin{array}{l}\text { Yes, at } \\
\text { reproductive pole }\end{array}$ & $\begin{array}{l}\text { Yes, at } \\
\text { reproductive } \\
\text { pole }\end{array}$ & $\begin{array}{l}\text { Yes, at } \\
\text { reproductive } \\
\text { pole }\end{array}$ & $\begin{array}{l}\text { Yes, at fibre } \\
\text { pole }\end{array}$ \\
\hline Fimbriae & Yes & Yes & Yes & Yes & Yes & Yes \\
\hline Bud shape & $\begin{array}{l}\text { Like mother } \\
\text { cell }\end{array}$ & $\begin{array}{l}\text { Like mother } \\
\text { cell }\end{array}$ & Bean-shaped & $\begin{array}{l}\text { Like mother } \\
\text { cell }\end{array}$ & $\begin{array}{l}\text { Like mother } \\
\text { cell }\end{array}$ & $\begin{array}{l}\text { Like mother } \\
\text { cell }\end{array}$ \\
\hline Budding type & Polar & Polar & Polar & Polar & Polar & Polar \\
\hline Holdfast structure & Yes & Yes & Yes & Yes & Yes & No \\
\hline \multicolumn{7}{|l|}{ Genomic characteristics } \\
\hline Genome size (bp) & $8,439,957$ & $6,570,840$ & $6,663,851$ & $8,212,515$ & $6,196,199$ & $7,182,433$ \\
\hline Plasmids (bp) & No & No & n.d. & No & No & No \\
\hline $\mathrm{G}+\mathrm{C}(\%)$ & 55.3 & 53.4 & 57.0 & 59.1 & 57.5 & 57.8 \\
\hline Completeness (\%) & 98.12 & 98.28 & 96.55 & 98.28 & 98.28 & 95.69 \\
\hline Contamination (\%) & 1.72 & 1.72 & 1.72 & 1.72 & 1.72 & 0 \\
\hline Protein-coding genes & 6419 & 5123 & 5406 & 5815 & 4705 & 5437 \\
\hline Hypothetical proteins & 2988 & 2087 & 3023 & 2299 & 2601 & 2117 \\
\hline Protein-coding genes/Mb & 761 & 780 & 777 & 708 & 720 & 757 \\
\hline Coding density (\%) & 85.0 & 88.8 & 86.8 & 87.5 & 86.2 & 88.5 \\
\hline tRNAs & 82 & 65 & 56 & 71 & 49 & 45 \\
\hline 16S rRNA & 2 & 1 & 1 & 1 & 1 & 1 \\
\hline
\end{tabular}

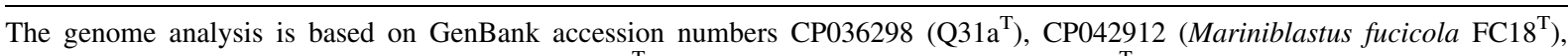
GCF_000153105 (Blastopirellula marina DSM 3645 $\left.{ }^{\mathrm{T}}\right), \mathrm{CP} 042914\left(\right.$ Roseimaritima ulvae $\left.\mathrm{UC}^{\mathrm{T}}\right)$, GCF_000025185 (Pirellula staleyi DSM $6068^{\mathrm{T}}$ ) and CP036319 (Crateriforma conspicua Mal65 $^{\mathrm{T}}$ )

The closed genome harbours 6419 protein-coding genes, almost half of which are annotated as hypothetical proteins (2988 genes, 47\%). The number of protein-coding genes yields 761 genes per $\mathrm{Mb}$ and a coding density of $85.0 \% .82$ tRNAs are encoded and two copies of the 16S rRNA gene are present. In comparison to close relatives, $\mathrm{Q} 31 \mathrm{a}^{\mathrm{T}}$ has the largest genome and the highest number of protein-coding 

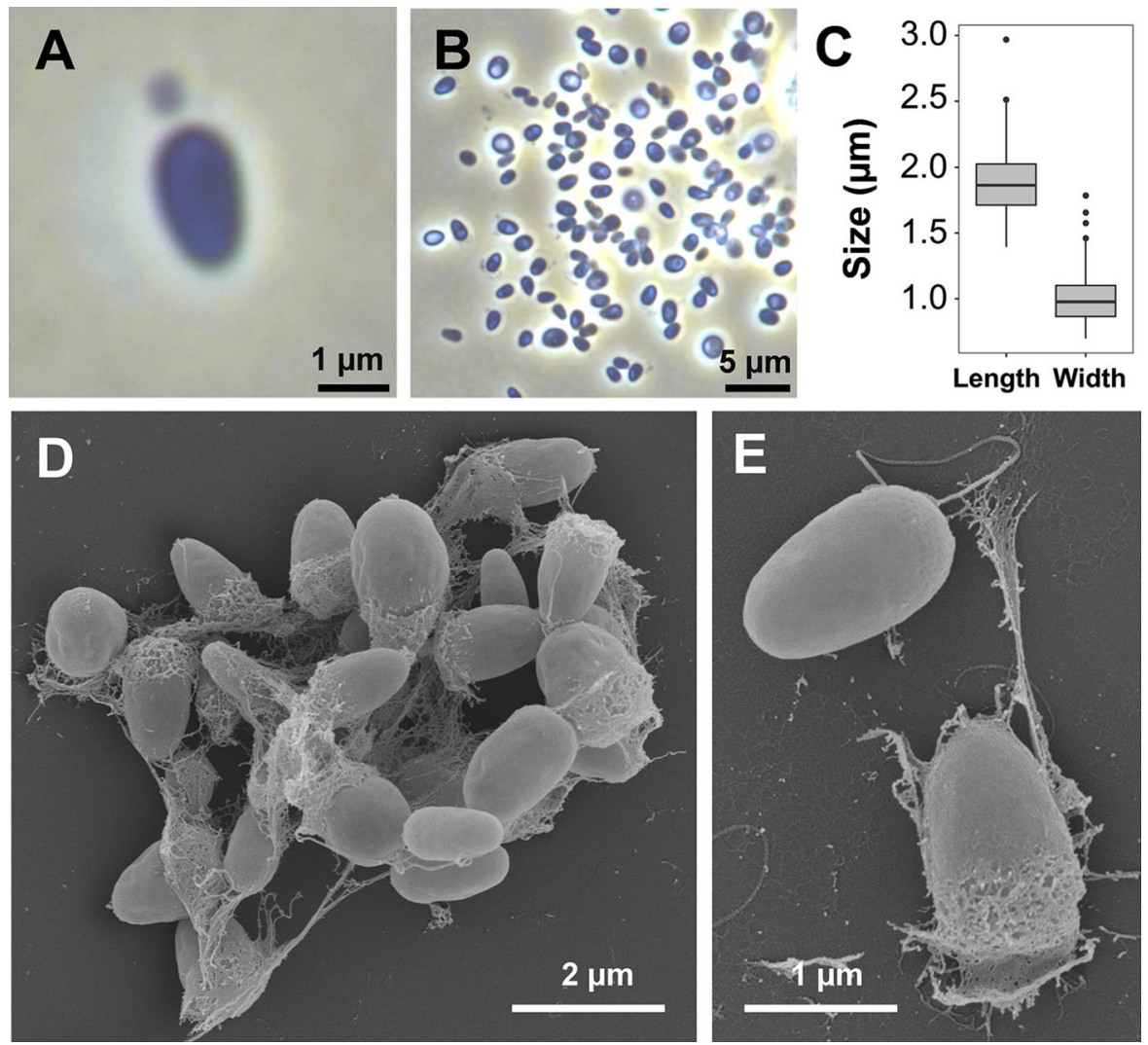

Fig. 3 Microscopy images and cell size plot of strain Q31a ${ }^{\mathrm{T}}$. The mode of cell division (a) and a general overview of cell morphology (b, d, e) are shown in the pictures. For
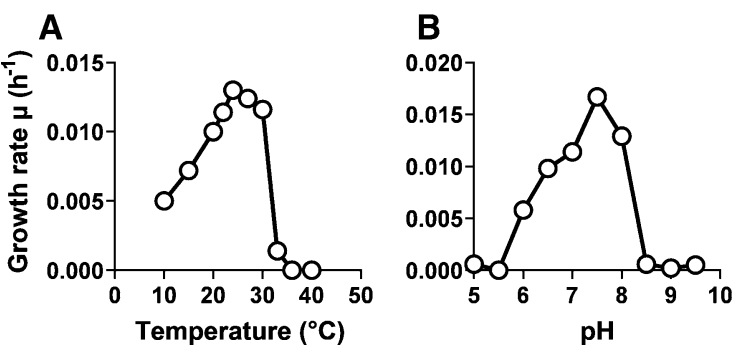

Fig. 4 Temperature and $\mathrm{pH}$ optimum of $\mathrm{Q} 31 \mathrm{a}^{\mathrm{T}}$. The graphs show the average growth rates obtained from cultivation of Q31 $\mathrm{a}^{\mathrm{T}}$ in M1H NAG ASW medium in biological triplicates. Cultivations at different $\mathrm{pH}$ values were conducted at $28^{\circ} \mathrm{C}$ and cultivations at different temperatures were performed at $\mathrm{pH} 7.5$

genes, tRNA- and 16S rRNA genes, but a lower $\mathrm{G}+\mathrm{C}$ content $\left(55 \%\right.$ for $\mathrm{Q} 31 \mathrm{a}^{\mathrm{T}}$ vs. $57-59 \%$ for the other species, except $M$. fucicola, 53\%). The number of protein-coding genes per $\mathrm{Mb}$ (710-780) is comparable for all six strains, however the coding density of determination of the cell size (c) at least 100 representative cells were counted manually or by using a semi-automated object count tool

$85 \%$ of $\mathrm{Q} 31 \mathrm{a}^{\mathrm{T}}$ is slightly lower compared to the other five species $(87-89 \%)$.

Genome-based analysis of metabolic features

Numbers of carbohydrate-active enzymes and secondary metabolite-associated genes clusters were analysed based on the genome sequences of $\mathrm{Q} 31 \mathrm{a}^{\mathrm{T}}$ and type species of related genera (Table 2). These numbers give a first impression on the potential of Q31 ${ }^{\mathrm{T}}$ for degradation of complex and highly decorated polysaccharides and for production of bioactive small molecules. In total, $\mathrm{Q} 31 \mathrm{a}^{\mathrm{T}}$ harbours 159 carbohydrate-active enzyme as currently listed in the CAZY database. This number is comparable to $R$. ulvae $\mathrm{UC}^{\mathrm{T}}$, which also has a similar genome size. Although having a genome $1.3 \mathrm{Mb}$ smaller than $\mathrm{Q} 31 \mathrm{a}^{\mathrm{T}}$, the highest number of 217 carbohydrate-active enzymes was observed in C. conspicua Mal65 ${ }^{\mathrm{T}}$. This difference can mainly be attributed to the glycoside hydrolase 
Table 2 Numbers of carbohydrate-active enzymes and putative gene clusters involved in the production of secondary metabolites

\begin{tabular}{|c|c|c|c|c|c|c|}
\hline & $\mathrm{Q} 1 \mathrm{a}^{\mathrm{T}}$ & $\begin{array}{l}\text { M. fucicola } \\
\text { FC } 18^{\mathrm{T}}\end{array}$ & $\begin{array}{l}\text { B. marina } \\
\text { DSM } 3645^{\mathrm{T}}\end{array}$ & $\begin{array}{l}\text { R. ulvae } \\
\mathrm{UC}^{\mathrm{T}}\end{array}$ & $\begin{array}{l}\text { P. staleyi } \\
\text { DSM } 6068^{\mathrm{T}}\end{array}$ & $\begin{array}{l}\text { C. conspicua } \\
{\text { Mal } 65^{\mathrm{T}}}\end{array}$ \\
\hline Genome size $(\mathrm{Mb})$ & 8.44 & 6.57 & 6.66 & 8.21 & 6.20 & 7.18 \\
\hline \multicolumn{7}{|l|}{ Carbohydrate-active enzymes } \\
\hline Glycoside hydrolase family & 52 & 44 & n.d. & 45 & 19 & 121 \\
\hline Glycosyltransferase family & 73 & 57 & n.d. & 76 & 49 & 65 \\
\hline Polysaccharide lyase family & 6 & 5 & n.d. & 3 & 1 & 7 \\
\hline Carbohydrate esterase family & 12 & 5 & n.d. & 7 & 8 & 9 \\
\hline Carbohydrate-binding module family & 16 & 15 & n.d. & 21 & 14 & 15 \\
\hline Total & 159 & 126 & n.d. & 152 & 91 & 217 \\
\hline \multicolumn{7}{|l|}{$\begin{array}{l}\text { Putative secondary metabolite-associated } \\
\text { genes clusters }\end{array}$} \\
\hline Terpene & 2 & 2 & 3 & 2 & 3 & 2 \\
\hline Type I PKS & 0 & 0 & 1 & 3 & 0 & 2 \\
\hline Type II PKS & 0 & 0 & 0 & 0 & 0 & 0 \\
\hline Type III PKS & 1 & 0 & 0 & 1 & 0 & 0 \\
\hline NRPS & 0 & 0 & 0 & 0 & 0 & 1 \\
\hline Type I-PKS-NRPS & 0 & 2 & 1 & 1 & 0 & 2 \\
\hline Bacteriocin & 1 & 0 & 1 & 0 & 1 & 0 \\
\hline Ectoine & 0 & 0 & 1 & 0 & 0 & 0 \\
\hline Resorcinol & 1 & 0 & 0 & 0 & 0 & 0 \\
\hline Other & 2 & 1 & 3 & 1 & 1 & 2 \\
\hline Total & 7 & 5 & 10 & 8 & 5 & 9 \\
\hline
\end{tabular}

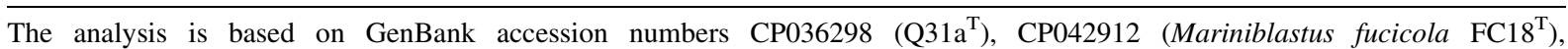
GCF_000153105 (Blastopirellula marina DSM 3645 ${ }^{\mathrm{T}}$ ), CP042914 (Roseimaritima ulvae UC8 ${ }^{\mathrm{T}}$ ), GCF_000025185 (Pirellula staleyi DSM $6068^{\mathrm{T}}$ ) and CP036319 (Crateriforma conspicua Mal65 ${ }^{\mathrm{T}}$ ). The genome of B. marina was not listed in the CAZY database

family, since 52 enzymes were found in $\mathrm{Q}^{3} 1 \mathrm{a}^{\mathrm{T}}$ and 121 in C. conspicua Mal65 ${ }^{\mathrm{T}}$. Q31 $\mathrm{a}^{\mathrm{T}}$ contains the highest number of enzymes of the carbohydrate esterase family of the species used for comparison.

During analysis of secondary metabolite-associated gene clusters a heterogeneous distribution for the investigated species was observed. While 2-3 terpenoid-related clusters were found in all species, other clusters putatively involved in the production of ectoine, resorcinol or non-ribosomal peptides seem to be restricted to individual genera. Similar results were obtained for comparison of type I and type III polyketide synthases (PKSs), while type II PKSs appear to be absent from the compared genomes. The total numbers of predicted clusters is between 5 and 10 , while higher numbers are not reflected by larger genomes in this case. Q31a ${ }^{\mathrm{T}}$ has the largest genome, but is ranked 3rd with regard to the number of gene clusters. In contrast, B. marina DSM $3645^{\mathrm{T}}$ has the highest number of predicted gene clusters, but is amongst the species with the smallest genomes.

\section{Conclusions}

The performed comparison of morphological, physiological and genomic features supports the results of the phylogenetic analysis that $\mathrm{Q} 31 \mathrm{a}^{\mathrm{T}}$ does not belong to the genera Mariniblastus, Pirellula, Blastopirellula, Rhodopirellula, Novipirellula, Rubripirellula, Bremerella, Crateriforma or Roseimaritima, but instead represents a new species belonging to a novel genus. 
Thus, we propose the name Aureliella helgolandensis gen. nov., sp. nov. for $\mathrm{Q} 31 \mathrm{a}^{\mathrm{T}}$ and propose this species as the type species of the genus and $\mathrm{Q} 31 \mathrm{a}^{\mathrm{T}}$ as the type strain of the novel species.

\section{Aureliella gen. nov.}

Aureliella (Au.re.li.el'la. N.L. fem. n. Aureliella dim. of Aurelia; a bacterium isolated from the common jellyfish Aurelia aurita).

Members of the genus are Gram-negative, aerobic, mesophilic, neutrophilic and heterotrophic. Cells are acorn-shaped, have crateriform structures at one pole and divide by polar budding. The genus belongs to the family Pirellulaceae, order Pirellulales, class Planctomycetia, phylum Planctomycetes. The type species is Aureliella helgolandensis.

\section{Aureliella helgolandensis sp. nov.}

Aureliella helgolandensis (hel.go.lan.den'sis N.L. fem. adj. helgolandensis of Helgoland; corresponding to the origin of the strain from the German island Helgoland).

Cells are $1.9 \pm 0.2 \mu \mathrm{m} \times 1.0 \pm 0.2 \mu \mathrm{m}$ in size and form aggregates. Matrix or fibre originates from the budding pole and a holdfast structure is present at the opposite pole. Grows at $10-33{ }^{\circ} \mathrm{C}$ (optimum $27{ }^{\circ} \mathrm{C}$ ) and at $\mathrm{pH}$ 6.0-8.0 (optimum 7.5). Colonies are lucid white. The genome of the type strain has a $\mathrm{G}+\mathrm{C}$ content of $55.3 \%$.

The type strain is $\mathrm{Q} 31 \mathrm{a}^{\mathrm{T}}\left(\mathrm{DSM} 103537^{\mathrm{T}}=\mathrm{LMG}\right.$ $29700^{\mathrm{T}}$ ), isolated from a jellyfish (Aurelia aurita) on the shore of Helgoland Island in June 2013. The type strain genome (8.44 Mb, acc. no. CP036298) and 16S rRNA gene sequence (acc. no. MK559992) are available from GenBank.

Acknowledgements Open Access funding provided by Projekt DEAL. Part of this research was funded by the Deutsche Forschungsgemeinschaft Grants KA 4967/1-1 and JO 893/4-1, Grant ALWOP.308 of the Nederlandse Organisatie voor Wetenschappelijk Onderzoek (NWO), SIAM (Soehngen Institute for Anaerobic Microbiology) Grant No. 024002002 and the Radboud Excellence fellowship. We thank Ina Schleicher for skillful technical assistance. Brian Tindall and Regine Fähnrich from the DSMZ as well as the BCCM/LMG Bacteria collection we thank for support during strain deposition. We thank Jörn Petersen (DSMZ) and the Biological Institute Helgoland (BAH) for sampling support.
Author contributions NK wrote the manuscript and analysed the cultivation data, SW performed the genomic and phylogenetic analysis, AH, PR and MJ isolated the strains and performed the initial cultivation and strain deposition, SHP and $\mathrm{CB}$ performed the light microscopic analysis and prepared the LM pictures, MSMJ contributed to text preparation and revised the manuscript, MR performed the electron microscopic analysis and prepared the SEM pictures, CJ supervised PR, $\mathrm{AH}$ and the study. All authors read and approved the final version of the manuscript.

\section{Compliance with ethical standards}

Conflict of interest The authors declare that they have no conflict of interest.

Ethical statement This article does not contain any studies with animals performed by any of the authors.

Open Access This article is licensed under a Creative Commons Attribution 4.0 International License, which permits use, sharing, adaptation, distribution and reproduction in any medium or format, as long as you give appropriate credit to the original author(s) and the source, provide a link to the Creative Commons licence, and indicate if changes were made. The images or other third party material in this article are included in the article's Creative Commons licence, unless indicated otherwise in a credit line to the material. If material is not included in the article's Creative Commons licence and your intended use is not permitted by statutory regulation or exceeds the permitted use, you will need to obtain permission directly from the copyright holder. To view a copy of this licence, visit http://creativecommons.org/licenses/by/4.0/.

\section{References}

Bengtsson MM, Øvreås L (2010) Planctomycetes dominate biofilms on surfaces of the kelp Laminaria hyperborea. BMC Microbiol 10:261

Blin K, Wolf T, Chevrette MG, Lu X, Schwalen CJ, Kautsar SA, Suarez Duran HG, de Los Santos EL, Kim HU, Nave M (2017) AntiSMASH 4.0-improvements in chemistry prediction and gene cluster boundary identification. Nucleic Acids Res 45:W36-W41

Boedeker C, Schuler M, Reintjes G, Jeske O, van Teeseling MC, Jogler M, Rast P, Borchert D, Devos DP, Kucklick M, Schaffer M, Kolter R, van Niftrik L, Engelmann S, Amann R, Rohde M, Engelhardt H, Jogler C (2017) Determining the bacterial cell biology of Planctomycetes. Nat Commun 8:14853

Boersma AS, Kallscheuer N, Wiegand S, Rast P, Peeters SH, Mesman RJ, Heuer A, Boedeker C, Jetten MS, Rohde M, Jogler M, Jogler C (2019) Alienimonas californiensis gen. nov. sp. nov., a novel Planctomycete isolated from the kelp forest in Monterey Bay. Antonie van Leeuwenhoek. https:// doi.org/10.1007/s10482-019-01367-4 
Bondoso J, Harder J, Lage OM (2013) rpoB gene as a novel molecular marker to infer phylogeny in Planctomycetales. Antonie Van Leeuwenhoek 104:477-488

Bondoso J, Balague V, Gasol JM, Lage OM (2014) Community composition of the Planctomycetes associated with different macroalgae. FEMS Microbiol Ecol 88:445-456

Bondoso J, Godoy-Vitorino F, Balague V, Gasol JM, Harder J, Lage OM (2017) Epiphytic Planctomycetes communities associated with three main groups of macroalgae. FEMS Microbiol Ecol 93:fiw255

Calisto R, Sæbø EF, Storesund JE, Øvreås L, Herfindal L, Lage OM (2019) Anticancer activity in planctomycetes. Front Mar Sci 5:499

Castresana J (2000) Selection of conserved blocks from multiple alignments for their use in phylogenetic analysis. Mol Biol Evol 17:540-552

Cayrou C, Raoult D, Drancourt M (2010) Broad-spectrum antibiotic resistance of Planctomycetes organisms determined by Etest. J Antimicrob Chemother 65:2119-2122

Dedysh SN, Kulichevskaya IS, Beletsky AV, Ivanova AA, Rijpstra WIC, Damsté JSS, Mardanov AV, Ravin NV (2019) Lacipirellula parvula gen. nov., sp. nov., representing a lineage of planctomycetes widespread in lowoxygen habitats, description of the family Lacipirellulaceae fam. nov. and proposal of the orders Pirellulales ord. nov., Gemmatales ord. nov. and Isosphaerales ord. nov. Syst Appl Microbiol 43:126050

Devos DP (2014) PVC bacteria: variation of, but not exception to, the gram-negative cell plan. Trends Microbiol 22:14-20

Edgar RC (2004) MUSCLE: multiple sequence alignment with high accuracy and high throughput. Nucleic Acids Res 32:1792-1797

Frank O, Michael V, Pauker O, Boedeker C, Jogler C, Rohde M, Petersen J (2014) Plasmid curing and the loss of grip: the 65-kb replicon of Phaeobacter inhibens DSM 17395 is required for biofilm formation, motility and the colonization of marine algae. Syst Appl Microbiol 38:120-127

Fuerst JA (1995) The planctomycetes: emerging models for microbial ecology, evolution and cell biology. Microbiology 141:1493-1506

Godinho O, Calisto R, Ovreas L, Quinteira S, Lage OM (2019) Antibiotic susceptibility of marine Planctomycetes. Antonie Van Leeuwenhoek 112:1273-1280

Graça AP, Calisto R, Lage OM (2016) Planctomycetes as novel source of bioactive molecules. Front Microbiol 7:1241

Jeske O, Jogler M, Petersen J, Sikorski J, Jogler C (2013) From genome mining to phenotypic microarrays: planctomycetes as source for novel bioactive molecules. Antonie Van Leeuwenhoek 104:551-567

Jeske O, Schüler M, Schumann P, Schneider A, Boedeker C, Jogler M, Bollschweiler D, Rohde M, Mayer C, Engelhardt H, Spring S, Jogler C (2015) Planctomycetes do possess a peptidoglycan cell wall. Nat Commun 6:7116

Jeske O, Surup F, Ketteniß M, Rast P, Förster B, Jogler M, Wink J, Jogler C (2016) Developing techniques for the utilization of Planctomycetes as producers of bioactive molecules. Front Microbiol 7:1242

Jogler M, Jogler C (2013) Towards the development of genetic tools for planctomycetes. In: Fuerst JA (ed) Planctomycetes: cell structure, origins and biology. Springer, Berlin, pp 141-164
Jogler C, Glöckner FO, Kolter R (2011) Characterization of Planctomyces limnophilus and development of genetic tools for its manipulation establish it as a model species for the phylum Planctomycetes. Appl Environ Microbiol 77:5826-5829

Jogler C, Waldmann J, Huang X, Jogler M, Glöckner FO, Mascher T, Kolter R (2012) Identification of proteins likely to be involved in morphogenesis, cell division, and signal transduction in Planctomycetes by comparative genomics. J Bacteriol 194:6419-6430

Kallscheuer N, Jogler M, Wiegand S, Peeters SH, Heuer A, Boedeker C, Jetten MS, Rohde M, Jogler C (2019a) $R u$ binisphaera italica sp. nov. isolated from a hydrothermal area in the Tyrrhenian Sea close to the volcanic island Panarea. Antonie van Leeuwenhoek. https://doi.org/10. 1007/s10482-019-01329-w

Kallscheuer N, Jogler M, Wiegand S, Peeters SH, Heuer A, Boedeker C, Jetten MS, Rohde M, Jogler C (2019b) Three novel Rubripirellula species isolated from plastic particles submerged in the Baltic Sea and the estuary of the river Warnow in northern Germany. Antonie van Leeuwenhoek. https://doi.org/10.1007/s10482-019-01368-3

Kallscheuer N, Moreira C, Airs R, Llewellyn CA, Wiegand S, Jogler C, Lage OM (2019c) Pink-and orange-pigmented Planctomycetes produce saproxanthin-type carotenoids including a rare C45 carotenoid. Environ Microbiol Rep 11:741-748

Kallscheuer N, Wiegand S, Peeters SH, Jogler M, Boedeker C, Heuer A, Rast P, Jetten MS, Rohde M, Jogler C (2019d) Description of three bacterial strains belonging to the new genus Novipirellula gen. nov., reclassificiation of Rhodopirellula rosea and Rhodopirellula caenicola and readjustment of the genus threshold of the phylogenetic marker rpoB for Planctomycetaceae. Antonie van Leeuwenhoek. https://doi.org/10.1007/s10482-019-01374-5

Kallscheuer N, Wiegand S, Heuer A, Rensink S, Boersma AS, Jogler M, Boedeker C, Peeters SH, Rast P, Jetten MS, Rohde M, Jogler C (2020) Blastopirellula retiformator $\mathrm{sp.}$ nov. isolated from the shallow-sea hydrothermal vent system close to Panarea Island. Antonie van Leeuwenhoek. https://doi.org/10.1007/s10482-019-01377-2

Kohn T, Wiegand S, Boedeker C, Rast P, Heuer A, Schüler M, Rohde C, Müller R-W, Brümmer F, Rohde M, Engelhardt H, Jogler M, Jogler C (2019) Planctopirus ephydatiae, a novel Planctomycete isolated from a freshwater sponge. Syst Appl Microbiol 43:126022

Konstantinidis KT, Tiedje JM (2005) Towards a genome-based taxonomy for prokaryotes. J Bacteriol 187:6258-6264

Lachnit T, Fischer M, Kunzel S, Baines JF, Harder T (2013) Compounds associated with algal surfaces mediate epiphytic colonization of the marine macroalga Fucus vesiculosus. FEMS Microbiol Ecol 84:411-420

Lage O, van Niftrik L, Jogler C, Devos D (2019) Planctomycetes. Encyclopedia of microbiology, fourth edition, reference module in life sciences. Elsevier, Amsterdam, pp 614-626

Lechner M, Findeiss S, Steiner L, Marz M, Stadler PF, Prohaska SJ (2011) Proteinortho: detection of (co-)orthologs in large-scale analysis. BMC Bioinform 12:124

Lee I, Ouk Kim Y, Park SC, Chun J (2016) OrthoANI: an improved algorithm and software for calculating average 
nucleotide identity. Int $\mathrm{J}$ Syst Evol Microbiol 66:1100-1103

Lombard V, Golaconda Ramulu H, Drula E, Coutinho PM, Henrissat B (2014) The carbohydrate-active enzymes database (CAZy) in 2013. Nucleic Acids Res 42:D490D495

Peeters SH, Wiegand S, Kallscheuer N, Jogler M, Heuer A, Jetten MS, Rast P, Boedeker C, Rohde M, Jogler C (2020) Three marine strains constitute the novel genus and species Crateriforma conspicua in the phylum Planctomycetes. Antonie van Leeuwenhoek. https://doi.org/10.1007/ s10482-019-01375-4

Pilhofer M, Rappl K, Eckl C, Bauer AP, Ludwig W, Schleifer KH, Petroni G (2008) Characterization and evolution of cell division and cell wall synthesis genes in the bacterial phyla Verrucomicrobia, Lentisphaerae, Chlamydiae, and Planctomycetes and phylogenetic comparison with rRNA genes. J Bacteriol 190:3192-3202

Pruesse E, Peplies J, Glöckner FO (2012) SINA: accurate highthroughput multiple sequence alignment of ribosomal RNA genes. Bioinformatics 28:1823-1829

Qin Q-L, Xie B-B, Zhang X-Y, Chen X-L, Zhou B-C, Zhou J, Oren A, Zhang Y-Z (2014) A proposed genus boundary for the prokaryotes based on genomic insights. J Bacteriol 196:2210-2215

Rast P, Glockner I, Boedeker C, Jeske O, Wiegand S, Reinhardt R, Schumann P, Rohde M, Spring S, Glockner FO, Jogler C, Jogler M (2017) Three novel species with Peptidoglycan cell walls form the new genus Lacunisphaera gen. nov. in the family Opitutaceae of the verrucomicrobial subdivision 4. Front Microbiol 8:202

Ravin NV, Rakitin AL, Ivanova AA, Beletsky AV, Kulichevskaya IS, Mardanov AV, Dedysh SN (2018) Genome analysis of Fimbriiglobus ruber SP5T, a planctomycete with confirmed chitinolytic capability. Appl Environ Microbiol 84:e02645-e02617

Rensink S, Wiegand S, Kallscheuer N, Rast P, Peeters SH, Heuer A, Boedeker C, Jetten MS, Rohde M, Jogler M, Jogler C (2020) Description of the novel planctomycetal genus Bremerella, containing Bremerella volcania sp. nov., isolated from an active volcanic site, and reclassification of Blastopirellula cremea as Bremerella cremea comb. nov. Antonie van Leeuwenhoek. https://doi.org/10. 1007/s10482-019-01378-1

Rivas-Marin E, Canosa I, Santero E, Devos DP (2016) Development of genetic tools for the manipulation of the Planctomycetes. Front Microbiol 7:914

Rodriguez-R LM, Konstantinidis KT (2016) The enveomics collection: a toolbox for specialized analyses of microbial genomes and metagenomes. PeerJ Prepr 4:e1900v1

Sievers F, Wilm A, Dineen D, Gibson TJ, Karplus K, Li W, Lopez R, McWilliam H, Remmert M, Söding J (2011) Fast, scalable generation of high-quality protein multiple sequence alignments using clustal omega. Mol Syst Biol 7:539

Staley J, Fuerst J, Giovannoni S, Schlesner H (1992) The order Planctomycetales and the genera Planctomyces, Pirellula, Gemmata, and Isosphaera. In: Balows A, Trüper HG, Dworkin M, Harder W, Schleifer K-H (eds) The prokaryotes. Springer, Berlin, pp 3710-3731

Stamatakis A (2014) RAxML version 8: a tool for phylogenetic analysis and post-analysis of large phylogenies. Bioinformatics 30:1312-1313

van Teeseling MC, Mesman RJ, Kuru E, Espaillat A, Cava F, Brun YV, VanNieuwenhze MS, Kartal B, van Niftrik L (2015) Anammox Planctomycetes have a peptidoglycan cell wall. Nat Commun 6:6878

Vollmers J, Frentrup M, Rast P, Jogler C, Kaster AK (2017) Untangling genomes of novel Planctomycetal and Verrucomicrobial species from Monterey Bay Kelp forest metagenomes by refined binning. Front Microbiol 8:472

Wagner M, Horn M (2006) The Planctomycetes, Verrucomicrobia, Chlamydiae and sister phyla comprise a superphylum with biotechnological and medical relevance. Curr Opin Biotechnol 17:241-249

Ward NL (2010) Phylum XXV. Planctomycetes Garrity and Holt 2001, 137 emend. Ward (this volume). In: Krieg NR, Staley JT, Brown DR, Hedlund BP, Paster BJ, Ward NL, Ludwig W, Whitman WB (eds) Bergey's manual of systematic bacteriology. Springer, Berlin, pp 879-925

Wiegand S, Jogler M, Jogler C (2018) On the maverick Planctomycetes. FEMS Microbiol Rev 42:739-760

Wiegand S, Jogler M, Boedeker C, Pinto D, Vollmers J, RivasMarín E, Kohn T, Peeters SH, Heuer A, Rast P, Oberbeckmann S, Bunk B, Jeske O, Meyerdierks A, Storesund JE, Kallscheuer N, Lücker S, Lage OM, Pohl T, Merkel BJ, Hornburger P, Müller R-W, Brümmer F, Labrenz M, Spormann AM, Op den Camp H, Overmann J, Amann R, Jetten MSM, Mascher T, Medema MH, Devos DP, Kaster A-K, Øvreås L, Rohde M, Galperin MY, Jogler C (2020) Cultivation and functional characterization of 79 Planctomycetes uncovers their unique biology. Nat Microbiol 5:126-140

Yarza P, Yilmaz P, Pruesse E, Glöckner FO, Ludwig W, Schleifer KH, Whitman WB, Euzeby J, Amann R, RosselloMora R (2014) Uniting the classification of cultured and uncultured bacteria and archaea using 16S rRNA gene sequences. Nat Rev Microbiol 12:635-645

Publisher's Note Springer Nature remains neutral with regard to jurisdictional claims in published maps and institutional affiliations. 